\title{
Growth responses of the nuisance algae Gonyostomum semen (Raphidophyceae) to DOC and associated alterations of light quality and quantity
}

\author{
Camilla Hedlund Corneliussen Hagman ${ }^{1,2, *}$, Birger Skjelbred ${ }^{1}$, Jan-Erik Thrane ${ }^{1}$, \\ Tom Andersen ${ }^{3}$, Heleen A. de Wit ${ }^{1}$ \\ ${ }^{1}$ Norwegian Institute for Water Research (NIVA), 0349 Oslo, Norway \\ ${ }^{2}$ Norwegian University of Life Sciences (NMBU), 1432 Ås, Norway \\ ${ }^{3}$ University of Oslo (UiO), 0316 Oslo, Norway
}

\begin{abstract}
In recent decades, the freshwater alga Gonyostomum semen (Ehrenberg) Diesing has increased in abundance and distribution, which has created problems regarding the use of lakes for drinking water and recreation. Increases in lake dissolved organic carbon (DOC; browning) and climate warming are among current hypotheses that explain the phenomenon of increased abundance of $G$. semen. A replicated, multifactorial laboratory experiment was performed in order to test the effects of DOC and light quality and irradiance on growth of G. semen in 96-well plates. Each well had a separate light source, creating a gradient of irradiance (10$140 \mu \mathrm{mol}$ photons $\mathrm{m}^{-2} \mathrm{~s}^{-1}$ ) and wavelength (white, red, green and blue), combined with a DOC gradient (0-50 $\left.\mathrm{mg} \mathrm{C}^{-1}\right)$, all within representative ranges for the summer epilimnion in boreal waters. The experiment showed that growth of $G$. semen was significantly enhanced by the addition of DOC. No growth response relating to wavelengths was found, but where irradiance was inhibitory, a shading effect from DOC was evident. A composed response to increases in DOC suggests a versatility of $G$. semen that gives it a competitive advantage over other phytoplankton in humic lake ecosystems. Hence, further increases in abundance and bloom frequency of G. semen as browning continues in boreal lakes are to be expected.
\end{abstract}

KEY WORDS: Gonyostomum semen $\cdot$ DOC $\cdot$ Lake browning $\cdot$ Light availability

\section{INTRODUCTION}

Over the past decades, there has been a growing interest in the photosynthetic freshwater flagellate Gonyostomum semen, whose presence and mass occurrences have been reported from an increasing number of Northern European lakes (Lepistö et al. 1994, Rengefors et al. 2012, Hagman et al. 2015). Gonyostomum semen, with the observed large biovolumes and numbers, its periodic domination of the phytoplankton community and the release of a mucilaginous substance with associated skin irritation,

${ }^{*}$ Corresponding author: camilla.corneliussen@niva.no has a long record of negatively impacting bathing water quality in Nordic countries, going back to 1948 in Lake Helgasjön in Sweden (Sörensen 1954). Other lakes in that region were also impacted at the same time, and later, similar challenges were reported from Lake Sjöatorpsjön in Sweden and the Norwegian lakes Lundebyvann, Vansjø and Bøvika (Sörensen 1954, Bjørndalen \& Løvstad 1984, Cronberg et al. 1988, Hagman et al. 2015). Additionally, the biomass and slime of $G$. semen leads to difficulties with sampling through plankton nets (Bjørndalen 1982, C.H.C.H. \& B.S. pers. obs.). G. semen can also pose

() The authors 2019. Open Access under Creative Commons by Attribution Licence. Use, distribution and reproduction are unrestricted. Authors and original publication must be credited. 
challenges for the classification of waters under the EU Water Framework Directive, due to the high chlorophyll a (chl a) to phosphorus ratios G. semen creates compared to other planktonic algae (Cronberg et al. 1988, Hongve et al. 1988, Hagman et al. 2015). This alga is therefore perceived as a nuisance species. Initial observations and publications suggested that this species preferred small, shallow and humic lakes, often associated with low pH (Cronberg et al. 1988, Hongve et al. 1988, Brettum \& Andersen 2005). Later publications show that G. semen is much broader in its preferences concerning physiological and chemical factors such as lake size, water colour and nutrients, although it does not necessarily occur in large volumes (Eloranta \& Järvinen 1991, Hagman et al. 2015, Sassenhagen et al. 2015). Mass occurrences however, have been connected to a combination of multiple factors such as lack of grazers, increased dissolved organic matter (DOM), low $\mathrm{pH}$ and higher water temperature (Findlay et al. 2005, Lebret et al. 2012, Rengefors et al. 2012, Trigal et al. 2013, Hagman et al. 2015, Sassenhagen et al. 2015). Responses of $G$. semen to temperature have already been studied in laboratory experiments (Rengefors et al. 2012), in addition to its edibility (Lebret et al. 2012, Johansson et al. 2013). However, the effects of DOM on growth have not been substantiated experimentally, and remain rather uncertain. On the one hand, G. semen in culture showed a preference for the presence of fulvic acid (Rengefors et al. 2008), and in another study showed inhibition by dissolved organic carbon (DOC) (Sassenhagen et al. 2015). On the other hand, observations of mass occurrences suggest a preference for humic lakes (Trigal et al. 2013). The present study therefore focuses on DOC and the effects of the changes in light availability and quality that follow increased browning. DOM is often measured by its proxy, dissolved organic carbon (DOC), which is the main constituent of humic compounds in humic, northern lakes and is primarily of terrestrial, allochthonous origin. In boreal lakes, DOC has increased over the past decades, presumably as a consequence of reduced acid deposition (de Wit et al. 2007, Monteith et al. 2007), a trend that is expected to continue under climate change (de Wit et al. 2016). Among the probable impacts of increases in DOC levels and consequent browning of waters on lake constituents and ecosystems are the pronounced and mainly negative effects due to reduction of light availability. DOC has a severe negative impact on light conditions for general lake phytoplankton by absorbing a large fraction of the photons in the region of photosynthetically active radiation (PAR)
(Thrane et al. 2014). This reduces the phytoplankton's light availability and, thus, primary productivity (Carpenter et al. 1998, Thrane et al. 2014). The largest shading effect by DOC is expected to be in the blue part of the PAR spectrum, meaning that wavelengths that are most important for absorption by photosynthetic pigments (chlorophylls) and lightharvesting pigments (e.g. carotenoids) will be the most diminished (Kirk 1976, 1983). After blue, the green wavelengths will be absorbed, leaving the red wavelengths to be the most abundant in humic lakes (Kirk 1976). The ability of phytoplankton species to absorb and use different light qualities in terms of wavelengths for photosynthesis, or to grow under different light intensities (irradiances), will therefore be of great importance for the planktonic ecosystem composition and lake primary productivity.

Multiple factors may explain why G. semen is particularly successful in humic lakes. It might be related to competitive disadvantages in clearwater lakes caused by light sensitivity (Eloranta \& Räike 1995) or its slow growth rate compared to that of other phytoplankton (Sassenhagen et al. 2015). Alternately, the success might be caused by competitive advantages in humic conditions. For instance, G. semen is suspected to possess the ability to utilize humic substances directly as a carbon source; also, based on the recent findings of photosynthetic pigments and carotenoids in G. semen cells, we would expect that this alga is able to utilize both green and red light in addition to blue light (Kirk 1983, Rengefors et al. 2008, Sassenhagen et al. 2014). The altered light conditions caused by DOC that will have negative effects on phytoplankton in general might give certain algal groups a competitive advantage if they are able to benefit from these conditions (Kirk 1977, Thrane et al. 2014). High DOC conditions generally create a shift from non-flagellated to flagellated autotrophs, with groups such as cryptophytes and ochrophytes becoming increasingly dominant (Deininger et al. 2017, Urrutia-Cordero et al. 2017). Previous experiments showed that $G$. semen performs diel vertical migration (DVM) both for nutrient uptake and to avoid light intensities above 75-95 $\mu \mathrm{mol}$ photons $\mathrm{m}^{-2} \mathrm{~s}^{-1}$, suggesting that this alga might be successful at lower light intensities such as those found in humic lakes (Eloranta \& Räike 1995).

Increased lake DOC and the subsequent changes in lake light regimes is thus likely to affect the behavior and success of several species and taxonomic groups, including G. semen. Understanding the responses, especially concerning such nuisance species, is crucial for the ability to manage water re- 
sources and predict needs in management. However, knowledge on the responses of this alga to such conditions is scarce. Therefore, a replicated, multifactorial growth experiment was performed, where DOC, light quality (wavelength) and light quantity (irradiance) varied within environmentally relevant ranges. The experiment was conducted to test the following hypotheses: (1) DOC facilitates growth of G. semen, (2) growth of $G$. semen is impacted by shading from DOC at strong light intensities and (3) G. semen is able to grow equally well under different light quality conditions associated with DOC. The effects of DOC, light quality and irradiance on growth of G. semen were tested as single and interacting factors.

\section{MATERIALS AND METHODS}

\section{Algal culture}

The culture of Gonyostomum semen ((Ehrenberg) Diesing; Raphidophyceae) NIVA-7/05 from the Norwegian Culture Collection of Algae (NORCCA) was chosen for its relatively fast growth and also because this strain, unlike many others of this species, is easy to grow and keep in culture. This strain was isolated from Lake Vansjø (southeastern Norway) in 2005 at a station known for high concentrations of G. semen (Grepperødfjorden). Average total phosphorus was $37 \mu \mathrm{g} \mathrm{l}^{-1}$, TOC was $7.85 \mathrm{mg} \mathrm{Cl}^{-1}$ and colour was $43 \mathrm{Pt}$ $\mathrm{l}^{-1}$ from April to October in 2005; the average total nitrogen was $740 \mathrm{\mu g} \mathrm{l}^{-1}$ from June to October 2007 (2005 values were not available) (Aquamonitor, www. aquamonitor.no). Prior to this experiment, the culture was acclimatized for at least 4 mo in a $100 \%$ solution of Z8 medium (Staub 1961, Kotai 1972) with added vitamins thiamine $\left(100 \mathrm{\mu g} \mathrm{l}^{-1}\right)$, biotin $\left(1 \mathrm{\mu g} \mathrm{l}^{-1}\right)$ and cobalamin $\left(1 \mu \mathrm{g} \mathrm{l}^{-1}\right)$, at $20 \pm 2^{\circ} \mathrm{C}$, and a $16 \mathrm{~h}$ light: $8 \mathrm{~h}$ dark cycle at approximately $19 \pm 0.2 \mu \mathrm{mol}$ photons $\mathrm{m}^{-2} \mathrm{~s}^{-1}$. The $\mathrm{Z} 8$ medium contains a surplus of major nutrients $\mathrm{P}\left(5.5 \mathrm{mg} \mathrm{l}^{-1}\right)$ and $\mathrm{N}\left(84 \mathrm{mg} \mathrm{l}^{-1}\right)$, in addition to $\mathrm{K}\left(14 \mathrm{mg} \mathrm{l}^{-1}\right), \mathrm{Ca}\left(10 \mathrm{mg} \mathrm{l}^{-1}\right), \mathrm{Mg}$ $\left(2.5 \mathrm{mg} \mathrm{l}^{-1}\right), \mathrm{S}\left(3.25 \mathrm{mg} \mathrm{l}^{-1}\right), \mathrm{Fe}$ $\left(0.58 \mathrm{mg} \mathrm{l}^{-1}\right)$, EDTA $\left(3.7 \mathrm{mg} \mathrm{l}^{-1}\right)$ and trace elements $\mathrm{W}, \mathrm{Mo}, \mathrm{Br}, \mathrm{I}, \mathrm{Zn}, \mathrm{Cd}$, $\mathrm{Co}, \mathrm{Cu}, \mathrm{Ni}, \mathrm{Cr}, \mathrm{V}, \mathrm{Al}, \mathrm{B}$ and $\mathrm{Mn}$.

\section{DOC source}

A major fraction of the DOC in lakes originates from terrestrial runoff (Thurman 1985). At NORCCA, a soil extract is used as an addition for cultivation of several algae species, among others $G$. semen. The extract is made from fresh, unfertilized garden soil, gently treated by sedimentation, filtrations through glass fiber $(\mathrm{GF} / \mathrm{C}, 1.2 \mu \mathrm{m})$ and membrane filters $(0.8 \mu \mathrm{m})$, followed by sterilization by autoclaving, after the description of the Culture Collection of Algae and Protozoa, England (Tompkins et al. 1995), and adapted by Randi Skulberg (Norwegian Institute for Water Research [NIVA]). We chose to use this extract as our DOC source for this experiment as it is of natural origin and insignificantly altered, e.g. not dried or frozen. The soil extract contains known amounts of $\mathrm{C}, \mathrm{P}$ and $\mathrm{N}$, among other nutrients naturally found in soil (Table 1). Results from analysis of the soil extract are given in Table 1 along with the methods used by NIVA's accredited laboratory.

\section{Experimental design}

The growth responses of $G$. semen were tested for combinations of DOC concentrations, light quality and light quantity under constant temperature (20 \pm $2^{\circ} \mathrm{C}$ ) in a multifactorial design. Experiments were conducted on altogether 4 white 96-well plates with clear, optical bottoms (Perkin-Elmer Optiplate ${ }^{\mathrm{TM}}$ 96). White wells were chosen to reduce light noise from adjacent wells when reading the fluorescence, and to reduce absorption and attenuation of light (Skjelbred et al. 2012), while optical bottoms ensured correct readings without reflection. Each treatment in the experiment was conducted with 2 replicates on each plate, and on 2 identical plates, creating a total of 4 replicates. The $100 \%$ Z8 solution with vitamins was the basic medium in all tests, providing the algae with a surplus of nutrients and trace metals. Each well contained $250 \mu \mathrm{l}$ of medium and $50 \mu \mathrm{l}$ of algal culture, giving a start concentration of approximately and at least 100 cells per well. The experiments were conducted in 8.1-mm-deep fluid. The soil extract was
Table 1. Some characteristics of soil extract used in the present study along with the methods used for analyses

\begin{tabular}{|lll|}
\hline Parameter & Concentration & Method \\
\hline Total P & $6.5 \mathrm{mg} \mathrm{l}^{-1}$ & Norwegian Standard, NS 4725:1984 \\
$\mathrm{PO}_{4}$ & $0.1 \mathrm{mg} \mathrm{l}^{-1}$ & Norwegian Standard, NS 4724:1984 \\
Total N & $161.5 \mathrm{mg} \mathrm{l}^{-1}$ & Norwegian Standard, NS 4743:1993 \\
$\mathrm{NO}_{3}-\mathrm{N}$ & $69 \mathrm{mg} \mathrm{l}^{-1}$ & Norwegian Standard, NS 4745:1991 \\
TOC & $1075 \mathrm{mg} \mathrm{Cl}^{-1}$ & Internal method (G 4-2), modified \\
& & Norwegian Standard, NS 1484:1997 \\
& & \\
\hline
\end{tabular}


added to the $\mathrm{Z} 8$ in 1,10 and $50 \mathrm{ml} \mathrm{l}^{-1}$, resulting in final concentrations of $0.9,9$ and $44.8 \mathrm{mg} \mathrm{C} \mathrm{l}^{-1}$ after inoculum of the culture. For simplicity, these concentrations are further referred to as 1,10 and $50 \mathrm{mg} \mathrm{C}$ $\mathrm{l}^{-1}$. These concentrations were chosen to include low conditions (1 $\left.\mathrm{mg} \mathrm{C}^{-1}\right)$, a typical Norwegian humic lake concentration of $10 \mathrm{mg} \mathrm{Cl}^{-1}$, and extreme conditions $\left(50 \mathrm{mg} \mathrm{C}^{-1}\right.$ ) covering the upper concentration of humic lakes with G. semen blooms (Sassenhagen 2015) and the potential concentrations with the predicted future increase in DOC and precipitation (de Wit et al. 2016). In addition, controls without soil extract were used. The plate rows were divided into the 4 DOC concentrations, 2 adjacent rows equal to each other. In Norway, the irradiance can be up to $2000 \mu \mathrm{mol}$ photons $\mathrm{m}^{-2} \mathrm{~s}^{-1}$ on terrestrial ground during mid-day in clear-weather, summer conditions. In clear or slightly humic lakes (DOC $<10 \mathrm{mg} \mathrm{Cl}^{-1}$ ), the attenuation coefficient is approximately 1 for PAR (Thrane et al. 2014); thus, irradiance can be as much as $100 \mu \mathrm{mol}$ photons $\mathrm{m}^{-2} \mathrm{~s}^{-1}$ at $3 \mathrm{~m}$ and $36 \mu \mathrm{mol}$ photons $\mathrm{s}^{-1}$ at $4 \mathrm{~m}$ depth. The experiment was therefore performed at an irradiance range from 10 to $140 \mu \mathrm{mol}$ photons $\mathrm{m}^{-2} \mathrm{~s}^{-1}$. In order to control the irradiance and wavelengths, 96 RGB LED boards created by Dead Bug Prototypes (https://tindie.com/stores/Dead_Bug_ Prototypes/) especially adapted for 96-well plates were used. One RGB LED board covered each experimental plate, with one LED point placed over each well. Each of the 96 LED lamps was programmed with Arduino software (Arduino $\mathrm{AG}^{\mathrm{TM}}$ ), resulting in 6 different irradiances: 10, 20, 30, 70, 110 and $140 \mu \mathrm{mol}$ photons $\mathrm{m}^{-2} \mathrm{~s}^{-1}$ ( 3 used per plate), each with 4 different wavelengths: white (red, blue and green in equal amounts), blue, green and red separated. Within each irradiance, the photon flux for each wavelength was adjusted to equal amounts so that wavelengths did not influence the irradiance. The growth plates were covered with BIO-RAD Microseal®'B'Seal, which is optically clear. The seals allowed gas exchange, light transmission and accurate and comparable fluorescence readings, the latter confirmed by our own preceding experiments (data not shown). An additional white 96-well plate without bottoms was placed between the experimental plates and the LED boards to create some distance to the light sources, and this also reduced the formation of humidity and droplets on the cover film. The plates were then incubated at $20 \pm 2^{\circ} \mathrm{C}$ for $20 \mathrm{~d}$. The LED boards were connected to a timer providing a $16 \mathrm{~h}$ light: $8 \mathrm{~h}$ dark cycle, simulating the typical Norwegian late summer daylight:darkness cycle. Growth was measured every 2-3 d using fluorescence.

\section{Growth measurement and determination}

Fluorescence was measured with a CytoFluor ${ }^{\mathrm{TM}}$ 2300 Fluorescence Measurement System (Millipore) using the program CytoFluor 2300-series System Version 2B2 (excitation $485 \mathrm{~nm}$, emission $685 \mathrm{~nm}$, sensitivity 4 ). The plates were checked visually in a magnifier each time to ensure that the readings were of actual living cells. The growth phase occurred for a majority of the treatments between 0 and $10 \mathrm{~d}$; consequently, this growth period was used for further analysis. Specific growth rate $\mu\left(\mathrm{d}^{-1}\right)$ in each experimental unit was calculated as the slope of a linear regression for log-transformed in vivo fluorescence against time. This data reduction gave a single specific growth rate estimate for each experimental combination. Growth rate was first plotted using an $x-y$ plot from the 'lattice' library, and all statistical analyses (simple ANOVA and pairwise comparisons) were performed in R (www.r-project.org). Significance was confirmed when $\mathrm{p} \leq 0.05$.

\section{RESULTS}

In general, Gonyostomum semen cultures have slow growth rates and may also need long periods of acclimatisation to new conditions. In this experiment, specific growth rates varied from 0 to $0.15 \mathrm{~d}^{-1}$. Growth started somewhat slow, and for most treatments declined after $10 \mathrm{~d}$. Fig. 1 shows growth rate $\left(\mathrm{d}^{-1}\right)$ plotted against irradiance for each of the different treatments of DOC and light quality (wavelengths), as average for the 4 replicates of each treatment.

\section{DOC}

Results showed significant positive effects of DOC on $G$. semen growth rates, as seen in Figs. $1 \& 2$ and confirmed by statistical analysis (ANOVA, p < 0.0001). The most pronounced effect was observed at intermediate or high DOC concentrations (10 and $50 \mathrm{mg}$ $\mathrm{C}^{-1}$ ), as confirmed by a subsequent pairwise comparison with the control (both $\mathrm{p}<0.0001$ ). There was little or no difference between the control and the lowest concentration of $1 \mathrm{mg} \mathrm{C}^{-1}$ ( $\left.\mathrm{p}>0.05\right)$. The positive effect of DOC on growth was most evident at higher light intensities $(\geq 70 \mu \mathrm{mol}$ photons $\mathrm{m}^{-2} \mathrm{~s}^{-1}$ ); however, it was also distinct at low-intermediate intensities $\left(20\right.$ and $30 \mu \mathrm{mol}$ photons $\mathrm{m}^{-2}$ $\mathrm{s}^{-1}$ ), where growth rates increased with increasing DOC (Figs. 1 \& 2). At high light intensities, only the 


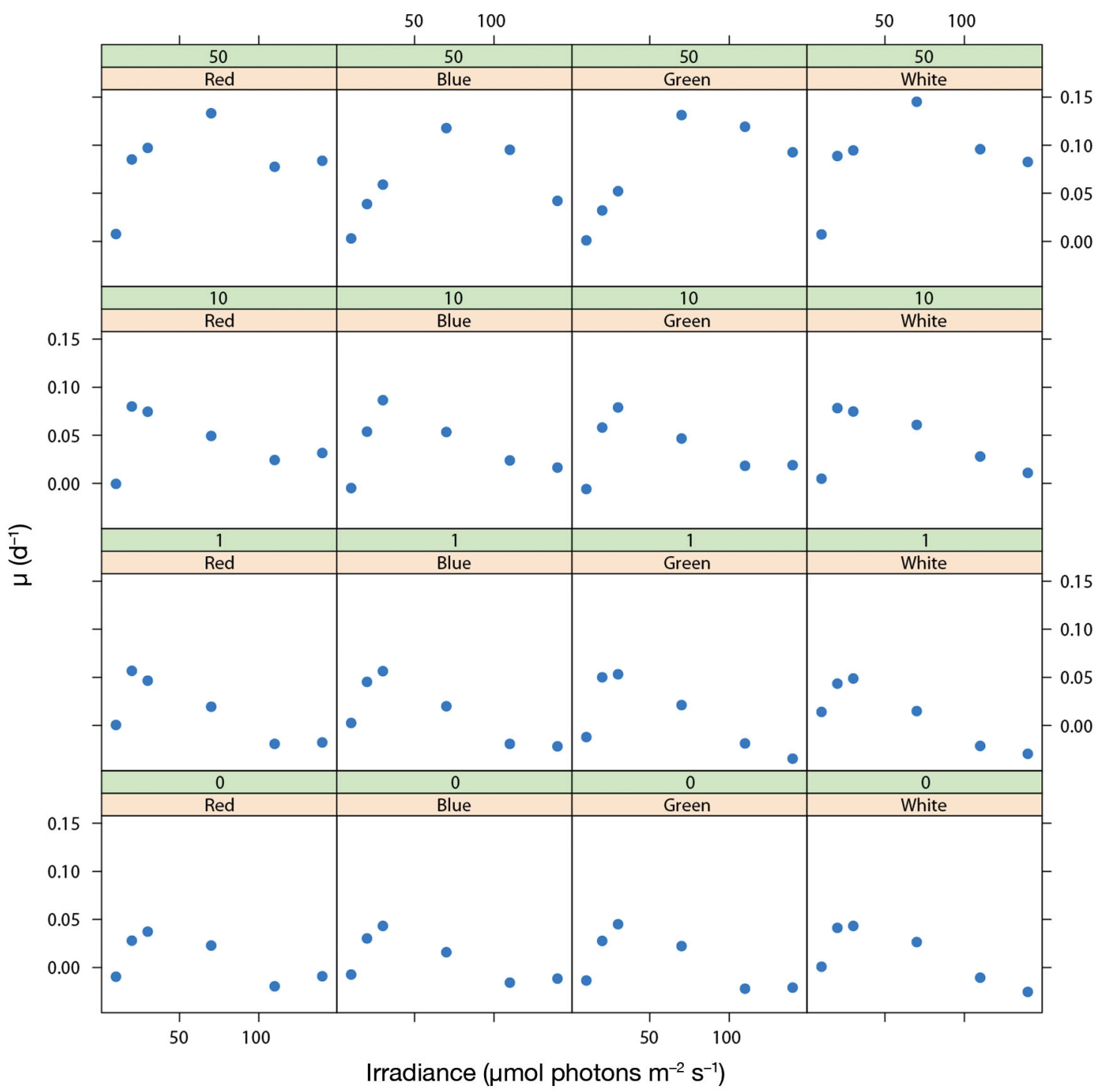

Fig. 1. Average growth rate $\left(\mu ; \mathrm{d}^{-1} ; y\right.$-axis) versus irradiance ( $x$-axis) for each combination of dissolved organic carbon (DOC $;$ $\mathrm{mg} \mathrm{l}^{-1}$ ) (rows) and wavelength (columns)

high DOC treatment affected growth positively. At low and intermediate DOC, there was no growth at these high light intensities, except at intermediate DOC in white light. At low irradiance $(10 \mu \mathrm{mol}$ photons $\mathrm{m}^{-2} \mathrm{~s}^{-1}$ ), there was a small positive effect of DOC concentrations of $1 \mathrm{mg} \mathrm{C}^{-1}$ in blue light and 1 and $10 \mathrm{mg} \mathrm{Cl}^{-1}$ in white light compared to the other DOC concentrations.

\section{Influence of light: irradiance and wavelength}

The minimum irradiance requirement in this experiment for positive growth rates of G. semen was slightly higher than $10 \mu \mathrm{mol}$ photons $\mathrm{m}^{-2} \mathrm{~s}^{-1}$, as can be seen in Fig. 1. Optimal growth rates occurred at intermediate irradiances of 20 and $30 \mu \mathrm{mol}$ photons $\mathrm{m}^{-2} \mathrm{~s}^{-1}$ when no DOC was added (Fig. 1). Overall, irradiance did not linearly affect growth rates of G. semen ( $p>0.05$ for the whole gradient), as growth was limited at 10 and $70 \mu \mathrm{mol}$ photons $\mathrm{m}^{-2} \mathrm{~s}^{-1}$ and inhibited above $70 \mu \mathrm{mol}$ photons $\mathrm{m}^{-2} \mathrm{~s}^{-1}$ without DOC. However, significant effects on growth up to $70 \mu \mathrm{mol}$ photons $\mathrm{m}^{-2} \mathrm{~s}^{-1}(\mathrm{p}<0.010)$ were found. In the $10 \mu \mathrm{mol}$ photons $\mathrm{m}^{-2} \mathrm{~s}^{-1}$ (low light) treatment, there was only growth in some treatments (blue light + $1 \mathrm{mg} \mathrm{C} \mathrm{l}^{-1}$ combination, and white light); however, the growth rates were extremely low. At irradiances of 20 and $30 \mu \mathrm{mol}$ photons $\mathrm{m}^{-2} \mathrm{~s}^{-1}$, there was growth in all treatments. At $70 \mu \mathrm{mol}$ photons $\mathrm{m}^{-2} \mathrm{~s}^{-1}$, there 


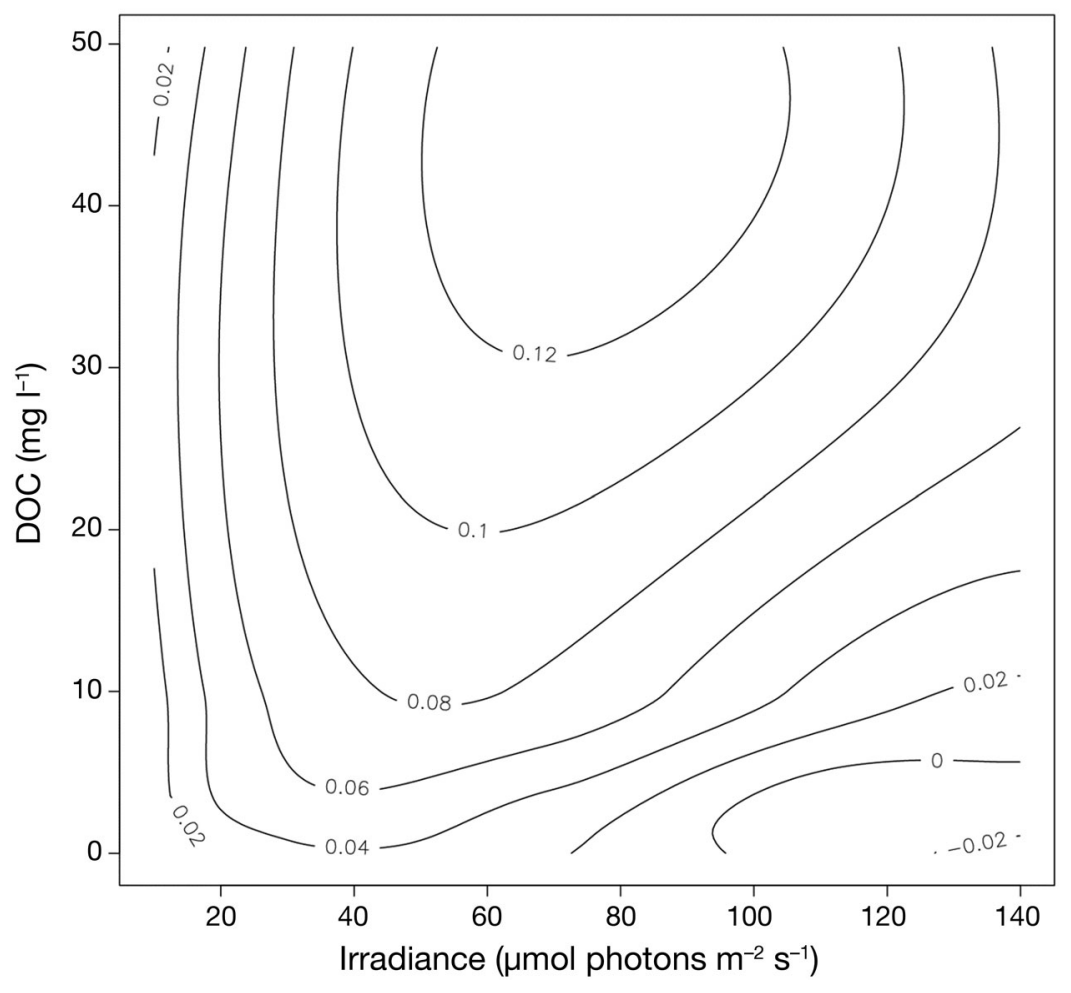

Fig. 2. Contour plot of specific growth rates $\left(\mu ; \mathrm{d}^{-1}\right)$ for each treatment combination of dissolved organic carbon (DOC $\mathrm{mg} \mathrm{l}^{-1}$ ) (y-axis) and irradiance (x-axis)

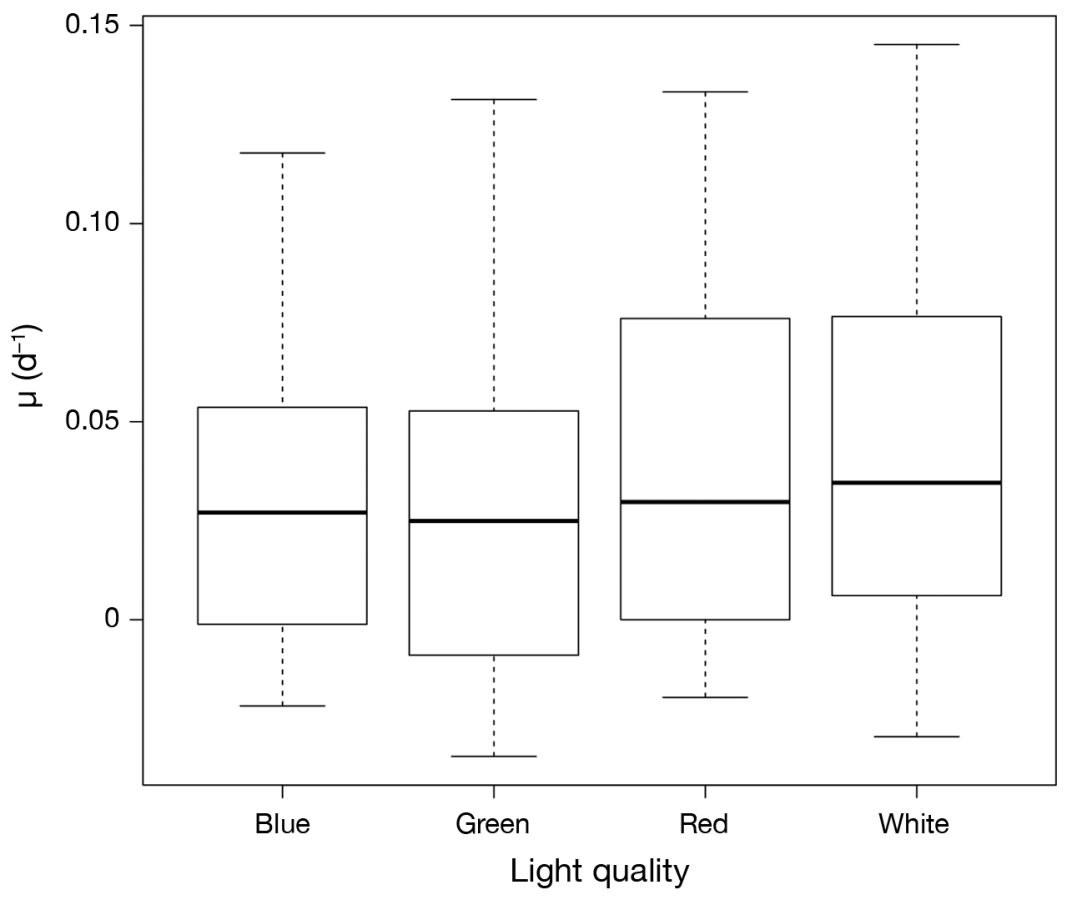

Fig. 3. Specific growth rates $\left(\mu ; \mathrm{d}^{-1}\right)$ as a function of the 4 different light qualities (wavelengths) tested were positive growth rates in all DOC and wavelength treatments; however, these were only barely positive in the control without DOC. In the high irradiance treatments of 110 and $140 \mu \mathrm{mol}$ photons $\mathrm{m}^{-2} \mathrm{~s}^{-1}$, there was growth only at the highest DOC concentration (50 $\mathrm{mg} \mathrm{C}^{-1}$ ) in all wavelength treatments. As demonstrated in Figs. 1 \& 2, the positive effect of irradiance on growth rates increased with increasing levels of DOC, due to decreased photoinhibition.

Light quality had no effect ( $p>0.05$ ) on the growth rate of our $G$. semen strain (Fig. 3). The lack of impact from the wavelength treatments was consistent across the gradients of irradiance and DOC.

\section{DISCUSSION}

In the multi-factorial experiment presented here, light quantity (irradiance) and quality (wavelength) were manipulated to simulate the impacts of DOC on the light regime in lakes. This set-up enabled single and interacting effects on growth of Gonyostomum semen to be demonstrated, and the results supported our hypotheses: DOC facilitated growth of $G$. semen when light was not inhibiting, and also prevented photoinhibition by shading at strong light intensities. Additionally, G. semen was able to grow equally well under different light qualities associated with DOC. The use of chl a as a measure of growth requires some consideration of the pigment acclimatization occuring in algal cells when they are exposed to differences in light quality and quantity. This is discussed for each variable in the following sections.

Maximum growth rates for $G$. semen were low (0-0.15 $\mathrm{d}^{-1}$ ) compared with other species, and this has also been confirmed by other experiments (Rengefors et al. 2012, Sassenhagen et al. 2015). Exact preferred concentrations and threshold values are not possible to determine from laboratory experiments 
since they do not reflect the natural environment where multiple factors interact simultaneously (Skjelbred et al. 2012). Hence, this paper focuses on the general impacts of the tested factors, although experimental values are discussed.

\section{DOC}

In Norway, the largest fraction of the G. semen biomass share in the phytoplankton communities is mainly found in lakes with a DOC content of 5 to $21 \mathrm{mg} \mathrm{C}^{-1}$ (B. Skjelbred unpubl. data), suggesting a preference for this interval of DOC concentrations. The results presented here are in agreement with this interval from monitoring data, as significant effects on growth from intermediate and high DOC concentrations (10 and $50 \mathrm{mg} \mathrm{C} \mathrm{l}^{-1}$ ) were found. At 20-30 $\mu \mathrm{mol}$ photons, DOC increased growth in terms of chl a. At these irradiance levels, there is no suspected photoinhibition taking place (referring to the lack of growth at $10 \mu \mathrm{mol})$. Hence, these increases in growth can be interpreted as utilization of DOC and not only as less photoinhibition. At higher irradiances, however (70 and above), growth in terms of chl a was reduced without DOC, while addition of DOC overruled this effect by increasing growth. At these high irradiances, the positive effect on growth is thus most probably due to shading. Increased irradiances (>25 $\mu \mathrm{mol}$ photons $\mathrm{m}^{2} \mathrm{~s}^{-1}$ ) should decrease the cell content of chl a (Sassenhagen et al. 2014), thus the observed increase in this experiment confirms that this growth increase is genuine. This should, however, be confirmed by further experiments on light inhibition or heterotrophic carbon uptake by G. semen. Contradicting results have been previously reported with regard to the effects of the addition of humic substances on G. semen growth. The addition of fulvic acid increased growth at $10 \mu \mathrm{mol}$ photons $\mathrm{m}^{2} \mathrm{~s}^{-1}$, and this was most significant at the lowest concentration $\left(0.9 \mathrm{mg} \mathrm{C}^{-1}\right)$, which is in accordance with our results showing a slight growth increase with $1 \mathrm{mg} \mathrm{Cl}^{-1}$ at a similar irradiance (Rengefors et al. 2008). We found little overall growth at this low irradiance, however, especially with additions of DOC $>1 \mathrm{mg} \mathrm{Cl}^{-1}$, which is also in accordance with observations of decreased growth by addition of higher concentrations $\left(\leq 9.5 \mathrm{mg} \mathrm{C}^{-1}\right.$ ) (Rengefors et al. 2008). However, differences in results would not be surprising as, even though carbon concentrations are given, DOC contains a range of various substances in addition to fulvic acid. Dried DOC (10-40 $\mathrm{mg} \mathrm{C}^{-1}$ ) decreased growth rates of several strains of G. semen (Sassenhagen et al. 2015) at
$25 \mu \mathrm{mol}$ photons $\mathrm{m}^{2} \mathrm{~s}^{-1}$, an irradiance at which we found significant positive effects of these DOC concentrations. Organic matter from varying sources and the use of different extracting methods will inevitably provide substances with differences in characteristics, composition and reactivity (Gjessing et al. 1999, Kitis et al. 2001), which may explain the differences in results between experiments. The growth medium we used for control and for dilution of DOC was rich in phosphorus, nitrogen and other nutrients, and contained a range of microelements and trace metals. Thus, the basic growth environment was saturated with nutrients. The positive effect on growth observed in the present study in addition to photoinhibition is thus likely to be a result from utilization of compounds in the soil extract. Soil contains micronutrients that algae may require, hence several algae, including $G$. semen, might benefit from this addition (Christensen 1982). DOM enhances phytoplankton's positive response to nutrients (measured as chl a) (Klug 2005), for which several explanations are possible. For instance, DOC can potentially contribute as a carbon source as G. semen is capable of heterotrophic carbon uptake (Rengefors et al. 2008). The humic colloids of soil can also act as buffers or chelators, creating less toxic and better conditions for algae (Jones 1998). A third explanation might be the role of bacteria, which may increase in numbers when DOC levels increase. On the one hand, bacterial competition for nutrients, especially phosphorus, can influence the growth of phytoplankton when organic carbon is added (Klug 2005). On the other hand, bacteria may influence algal growth by making nutrients from DOC more available, e.g. by being directly digested by mixotrophic algae; however, no evidence of bacterial ingestion by G. semen has yet been observed (Jones 1998, Rengefors et al. 2008). Both in cultivation at NORCCA and in this experiment, the bacterial numbers were kept as low as possible by using sterile techniques and equipment. In addition, in the present study, $G$. semen was given a surplus of available nutrients, thus the influence of bacteria on growth in this study is expected to be low. However, interactions between DOC, bacteria and G. semen were not investigated in this study, and bacterial influence cannot be discounted.

\section{Light quantity/irradiance}

With no DOC and in white light, the growth rates were low at $10 \mu \mathrm{mol}$ photons $\mathrm{m}^{-2} \mathrm{~s}^{-1}$. This is in accordance with previous work (Skjelbred et al. 2012). 
Also, the findings of a growth-limiting threshold at $70 \mu \mathrm{mol}$ photons $\mathrm{m}^{-2} \mathrm{~s}^{-1}$ is supported by previous research, as $G$. semen performs diel vertical migration, and has been found to avoid the surface area and strongest light intensities during the day, moving upwards from the sediments to about 75-95 $\mu \mathrm{mol}$ photons $\mathrm{m}^{-2} \mathrm{~s}^{-1}$ (Cronberg et al. 1988, Eloranta \& Räike 1995). The culture was only acclimatized to approximately $19 \mu \mathrm{mol}$ photons $\mathrm{m}^{-2} \mathrm{~s}^{-1}$ prior to the experiments, possibly influencing the algae to favor this condition and be limited by any alterations in irradiance. However, growth increased towards $30 \mu \mathrm{mol}$ photons $\mathrm{m}^{-2} \mathrm{~s}^{-1}$ in all treatments without DOC. We therefore do not believe that acclimatization influenced our results. G. semen cells contain larger amounts of chl a when exposed to low irradiances, i.e. $\leq 25$ umol photons $\mathrm{m}^{2} \mathrm{~s}^{-1}$, and the chl a content decreases at irradiances of $\geq 150 \mu \mathrm{mol}$ photons $\mathrm{m}^{-2}$ $\mathrm{s}^{-1}$, as would be normal for most photosynthetic microalgae (Richardson et al. 1983, Sassenhagen et al. 2014). The expected response in this experiment using irradiances of $10-140 \mu \mathrm{mol}$ photons $\mathrm{m}^{-2} \mathrm{~s}^{-1}$ would thus be decreasing chl a with increasing irradiance. This was only observed at irradiance levels of $\geq 70 \mu \mathrm{mol}$ photons $\mathrm{m}^{-2} \mathrm{~s}^{-1}$, while chl a increased significantly from 10 to $30 \mu \mathrm{mol}$ photons $\mathrm{m}^{-2} \mathrm{~s}^{-1}$. The interpretation of these results thus leaves no doubt that the biomass of $G$. semen increases at 20-30 $\mu \mathrm{mol}$ photons $\mathrm{m}^{-2} \mathrm{~s}^{-1}$ at such a magnitude that the reduction in chl $a$ is outweighed. Further, at higher irradiances, growth is reduced by photoinhibition at magnitudes lower or equal to the reduction in cell $\mathrm{chl} a$ content.

Upper layers of clear or slightly humic lakes (DOC $<10 \mathrm{mg} \mathrm{C}^{-1}$ ) where PAR can be more than $100 \mu \mathrm{mol}$ photons $\mathrm{m}^{-2} \mathrm{~s}^{-1}$ (Thrane et al. 2014) are thus not likely to harbor large amounts of $G$. semen. This alga prefers more humic conditions with less light penetration, or may exist at lower depths. Therefore, increases in lake DOC with associated decreases in irradiance are likely to facilitate the existence and growth of $G$. semen due to better conditions for growth and competition by the reduction of photoinhibition.

\section{Light quality/wavelength}

Results from this study supported the hypothesis regarding utilization of different wavelengths of light: the different wavelengths had no significant effect on the growth of $G$. semen, thus growth was not dependent on light quality, regardless of DOC and irradiance. The quantum of light, i.e. the amount of photons, was equal in all treatments. Hence, photosynthesis should theoretically also be the same as long as the algal cells are able to absorb the specific wavelengths of light (Kirk 1977). Photosynthetic activity and pigment composition, however, vary between algal groups, and information on the response and acclimatization of $G$. semen pigment content to different wavelengths is scarce. G. semen contains the photosynthetic pigments $\mathrm{chl} c 1, c 2$ and $a$, as well as several carotenoids (Guillard \& Lorenzen 1972, Sassenhagen et al. 2014). Chl $c 1, c 2$ and the carotenoids mainly absorb light in the blue region of the light spectrum, while chl a absorbs in both the blue and the red region (Kirk 1983). Therefore, most freshwater, planktonic algae species, as they contain $\mathrm{chl} a$, will prefer blue and red wavelengths for photosynthesis and growth. However, when chlorophylls and carotenoids are combined within a cell like in G. semen, the absorbance may shift towards the green region, creating the opportunity for the cells to utilize blue, red and green for photosynthesis (Kirk 1983), as confirmed by our results. Red light increases the chl a content of the cell equivalent to reduced irradiance $(25 \mu \mathrm{mol}$ red light corresponding to $5 \mu \mathrm{mol}$ white light) (Sassenhagen et al. 2014), which is expected based on algal cells' acclimatization to the reduced photon flux (Richardson et al. 1983). It would therefore be expected that, when given separate wavelengths of light at the same irradiance, chl a amounts would increase compared to that in white light, at least for red wavelengths. In contrast, this experiment shows that different wavelengths had no effect on the amount of chl $a$. Thus, if chl a actually increased as a response to red light compared to white, there was a high enough growth rate to conceal this reduction. Hence, this species' abilities regarding photosynthesis and growth are not dependent on certain wavelengths but can occur regardless of light quality.

This trait is probably of great advantage for G. semen in humic conditions, where the blue wavelengths will be absorbed first by the humic particles, then the green wavelengths and then red, thus leaving mostly red, less green and the least blue wavelengths available for photosynthesis.

\section{Combined effects}

Growth was normally inhibited at high light intensities $\left(>70 \mu \mathrm{mol}\right.$ photons $\mathrm{m}^{-2} \mathrm{~s}^{-1}$ ) without or with little DOC, but there was a clear positive effect on growth 
when DOC was added, increasing growth rates even at high light intensities, which is interpreted as a shading effect. The highest growth rate in the experiment was at $70 \mu \mathrm{mol}$ photons $\mathrm{m}^{-2} \mathrm{~s}^{-1}$ with $50 \mathrm{mg} \mathrm{C}$ $\mathrm{l}^{-1}$. At this combination, the alga was probably benefiting from both the direct effect of DOC and sufficient, but not inhibitory, irradiance.

Future climate predictions show that boreal lakes will probably contain more DOM, in addition to being warmer (O'Reilly et al. 2015, de Wit et al. 2016). It has already been shown that increased temperature is likely to facilitate expansion of G. semen, and that $\mathrm{pH}$ and absorbance may cause more frequent mass occurrences (Rengefors et al. 2012, Trigal et al. 2013); however, the positive effects of increased DOC on this alga has not been confirmed experimentally until now. Other studies have found a negative impact on lake primary productivity from increased DOC, mostly due to decreases in light availability and PAR (Thrane et al. 2014, Faithfull et al. 2015, Deininger et al. 2017, Hessen et al. 2017). Faithfull et al. (Faithfull et al. 2015) found differences in food web efficiency, zooplankton production, bacterial production and phytoplankton production between clear water and humic lake communities. Further, the loss of productivity, in combination with increased bacterial production and predation on bacteria, suggests that increased DOC levels may lead to more heterotrophy in lake ecosystems (Larsen et al. 2011). Thus, it is clear that increasing levels of lake DOC will influence lake primary productivity and ecosystems. The results from the present study indicate that the nuisance species $G$. semen will become more abundant as DOC levels increase, in contrast to many other phytoplankton species. Future scenarios where boreal lakes become warmer and more humic are likely to create the perfect conditions for $G$. semen to compete and grow, creating larger biomasses and more often dominating lake communities. As more lakes become humic, there will most likely also be a greater chance of observing this species in boreal lakes. Contrary to the expected negative effects on lake primary productivity (Thrane et al. 2014), the effect on $G$. semen from increased DOC might be the opposite, inducing more productivity from this algal species, as demonstrated by the results presented here. However, this experiment is limited to the direct effect of DOC and related light alterations, and does not provide information on the behavior of $G$. semen in regard to other factors or its contribution to lake heterotrophy. In natural lakes, a number of variables are present that may influence and overrule the impact of DOC on G. semen and phytoplankton in general. For instance, increased DOC normally also leads to increased nutrient loads, and the effect of DOC on phytoplankton in lakes will depend on both the simultaneous change in nutrients and the background nutrient values of the lake (Thrane et al. 2014). Although this potential increase in $G$. semen might be positive for primary productivity, the effect on the food web could be severe as this species is not often grazed upon and thus might replace phytoplankton that are food sources for zooplankton, creating disturbances in the lake ecosystem and shifts in the trophic chains (Lebret et al. 2012). Other phytoplankton species and taxonomic groups are also likely to benefit from increased lake DOC and/or light alterations (Urrutia-Cordero et al. 2017). However, when lake DOC and light attenuation are high, G. semen will have the combined competitive advantage of benefiting directly from DOC, tolerating the reduced light intensities created by increased humic conditions, and, finally, being able to equally absorb and use all available wavelengths of light, as shown in this experiment. As is already known, G. semen performs diurnal migration, possibly in order to avoid high light intensities, to take up nutrients from the sediments and/or to avoid grazers (Eloranta \& Räike 1995, Salonen \& Rosenberg 2000, Peczula et al. 2014). This experiment was conducted with excess nutrients, in shallow wells, leaving the algae no opportunity to avoid irradiance and also no eventual need for migration towards nutrients. Although this might have put the algae under stress, inhibiting growth, it also created the opportunity to investigate responses of controlled test conditions. In natural lakes, the ability to grow under different wavelengths should give G. semen a great advantage when it migrates towards the sediments, as it is able to adjust to the reduced irradiance as well as the loss of wavelengths following DOC additions.

\section{Conclusions}

DOC alone and in combination with alterations of light conditions associated with higher DOC will enhance the growth of $G$. semen in lakes. Because of the versatility of $G$. semen in using DOC and being unspecific in its light quality requirements, it will have great competitive advantages when DOC changes the availability and wavelengths of light in the water column. It can be expected that continued and future browning of lakes will contribute to the facilitation of growth of $G$. semen, and lead to larger and more frequent blooms. 
Acknowledgements. We owe a huge thanks to Vladyslava Hostyeva at NIVA for great laboratory help. We also thank the reviewers and editor for all the useful comments and suggestions which indeed improved the manuscript. This work was supported by the Research Council of Norway: ECCO (grant number 224779) to Dag O. Hessen and the NIVA Strategic Institute Programme (208279) to Øyvind Kaste.

\section{LITERATURE CITED}

Bjørndalen K (1982) Gonyostomum semen-en ny problemalge? Limnos 2:12-15

Bjørndalen K, Løvstad Ø (1984) En regionalundersøkelse av innsjøer i Østfold. Eutrofiering og problemalger. Vann 1: 10

Brettum P, Andersen T (2005) The use of phytoplankton as indicators of water quality. NIVA report 4818-2005, Norwegian Institute for Water Research

Carpenter SR, Cole JJ, Kitchell JF, Pace ML (1998) Impact of dissolved organic carbon, phosphorus, and grazing on phytoplankton biomass and production in experimental lakes. Limnol Oceanogr 43:73-80

Christensen T (1982) Alger i naturen og i laboratoriet. Nucleus, Denmark

Cronberg G, Lindmark G, Björk S (1988) Mass development of the flagellate Gonyostomum semen (Raphidophyta) in Swedish forest lakes - an effect of acidification? Hydrobiologia 161:217-236

de Wit HA, Mulder J, Hindar A, Hole L (2007) Long-term increase in dissolved organic carbon in stream waters in Norway is response to reduced acid deposition. Environ Sci Technol 41:7706-7713

de Wit HA, Valinia S, Weyhenmeyer GA, Futter MN and others (2016) Current browning of surface waters will be further promoted by wetter climate. Environ Sci Technol Lett 3:430-435

Deininger A, Faithfull CL, Bergstrom AK (2017) Phytoplankton response to whole lake inorganic $\mathrm{N}$ fertilization along a gradient in dissolved organic carbon. Ecology 98: 982-994

Eloranta P, Järvinen M (1991) Growth of Gonyostomum semen (Ehr.) Diesing (Raphidophyceae): results from culture experiments. Verh Internat Verein Limnol 24:2657-2659

Eloranta P, Räike A (1995) Light as a factor affecting the vertical distribution of Gonyostomum semen (Ehr.) Diesing (Raphidophyceae) in lakes. Aqua Fenn 25:15-22

Faithfull CL, Mathisen P, Wenzel A, Bergström AK, Vrede T (2015) Food web efficiency differs between humic and clear water lake communities in response to nutrients and light. Oecologia 177:823-835

Findlay DL, Paterson MJ, Hendzel LL, Kling HJ (2005) Factors influencing Gonyostomum semen blooms in a small boreal reservoir lake. Hydrobiologia 533:243-252

* Gjessing ET, Egeberg PK, Håkedal J (1999) Natural organic matter in drinking water-The 'NOM-typing project', background and basic characteristics of original water samples and NOM isolates. Environ Int 25:145-159

Guillard RRL, Lorenzen CJ (1972) Yellow-green algae with chlorophyllide c. J Phycol 8:10-14

Hagman CHC, Ballot A, Hjermann DO, Skjelbred B, Brettum P, Ptacnik R (2015) The occurrence and spread of Gonyostomum semen (Ehr.) Diesing (Raphidophyceae) in Norwegian lakes. Hydrobiologia 744:1-14

Hessen DO, Hall JP, Thrane JE, Andersen T (2017) Coupling dissolved organic carbon, $\mathrm{CO}_{2}$ and productivity in boreal lakes. Freshw Biol 62:945-953

Hongve D, Løvstad Ø, Bjørndalen K (1988) Gonyostomum semen-a new nuisance to bathers in Norwegian lakes. Verh Internat Verein Limnol 23:430-434

Johansson KSL, Vrede T, Lebret K, Johnson RK (2013) Zooplankton feeding on the nuisance flagellate Gonyostomum semen. PLOS ONE 8: e62557

Jones RI (1998) Phytoplankton, primary production and nutrient cycling. In: Hessen DO, Tranvik LJ (eds) Aquatic humic substances. Ecological studies (analysis and synthesis), Book 133. Springer, Berlin, p 145-175

Kirk JTO (1976) Yellow substance (Gelbstoff) and its contribution to the attenuation of photosynthetically active radiation in some inland and coastal south-eastern Australian waters. Aust J Mar Freshw Res 27:61-71

Kirk JTO (1977) Attenuation of light in natural waters. Aust J Mar Freshwater Res 28:12

Kirk JTO (1983) Light and photosynthesis in aquatic ecosystems. Press Syndicate of the University of Cambridge, Cambridge

K Kitis M, Kilduff JE, Karanfil T (2001) Isolation of dissolved organic matter (DOM) from surface waters using reverse osmosis and its impact on the reactivity of DOM to formation and speciation of disinfection by-products. Water Res 35:2225-2234

KKlug JL (2005) Bacterial response to dissolved organic matter affects resource availability for algae. Can J Fish Aquat Sci 62:472-481

Kotai J (1972) Instructions for preparation of modified nutrient solution Z8 for algae. Book B-11/69. Norwegian Institute for Water Research, Blindern, Oslo

KLarsen S, Andersen TOM, Hessen DO (2011) Climate change predicted to cause severe increase of organic carbon in lakes. Glob Change Biol 17:1186-1192

* Lebret K, Fernandez MF, Hagman CHC, Rengefors K, Hansson LA (2012) Grazing resistance allows bloom formation and may explain invasion success of Gonyostomum semen. Limnol Oceanogr 57:727-734

* Lepistö L, Antikainen S, Kivinen J (1994) The occurrence of Gonyostomum semen (Ehr.) Diesing in Finnish lakes. Hydrobiologia 273:1-8

Monteith DT, Stoddard JL, Evans CD, de Wit HA and others (2007) Dissolved organic carbon trends resulting from changes in atmospheric deposition chemistry. Nature 450:537-540

* O'Reilly CM, Sharma S, Gray DK, Hampton SE and others (2015) Rapid and highly variable warming of lake surface waters around the globe. Geophys Res Lett 42: 10773-10781

พ Peczula W, Mencfel R, Kowalczyk-Pecka D (2014) Amonglake variation in vertical distribution of invasive, bloomforming algal species Gonyostomum semen (Raphidophyceae) in stratified humic lakes of eastern Poland. Int Rev Hydrobiol 99:317-325

* Rengefors K, Pålsson C, Hansson LA, Heiberg L (2008) Cell lysis of competitors and osmotrophy enhance growth of the bloom-forming alga Gonyostomum semen. Aquat Microb Ecol 51:87-96

* Rengefors K, Weyhenmeyer GA, Bloch I (2012) Temperature as a driver for the expansion of the microalga Gonyostomum semen in Swedish lakes. Harmful Algae 18:65-73

* Richardson K, Beardall J, Raven JA (1983) Adaptation of unicellular algae to irradiance: an analysis of strategies. New Phytol 93:157-191 
Salonen K, Rosenberg M (2000) Advantages from diel vertical migration can explain the dominance of Gonyostomum semen (Raphidophyceae) in a small, steeply-stratified humic lake. J Plankton Res 22:1841-1853

Sassenhagen I, Rengefors K, Richardson TL, Pinckney JL (2014) Pigment composition and photoacclimation as keys to the ecological success of Gonyostomum semen (Raphidophyceae, Stramenopiles). J Phycol 50:1146-1154

Sassenhagen I, Wilken S, Godhe A, Rengefors K (2015) Phenotypic plasticity and differentiation in an invasive freshwater microalga. Harmful Algae 41:38-45

Skjelbred B, Edvardsen B, Andersen T (2012) A highthroughput method for measuring growth and loss rates in microalgal cultures. J Appl Phycol 24:1589-1599

Sörensen I (1954) Gonyostomum semen (Ehrenb.) Diesing en vattenorganism av teoretiskt och praktickt intresse. Svensk Faunistisk Revy 2:6

Staub R (1961) Ernährungsphysiologisch-autökologische Untersuchungen an der planktischen Blaualge Oscillato-

Editorial responsibility: Paul del Giorgio,

Montreal, Quebec, Canada ria rubescens DC. Schweiz Z Hydrol 23:82-198

* Thrane JE, Hessen DO, Andersen T (2014) The absorption of light in lakes: negative impact of dissolved organic carbon on primary productivity. Ecosystems 17: 1040-1052

Thurman EM (1985) Organic geochemistry of natural waters. Kluwer Academic Publishers, Dordrecht

Tompkins J, DeVille MM, Day JG, Turner MF (1995) Catalogue of strains. Culture Collection of Algae and Protozoa, Kendal, UK

Trigal C, Hallstan S, Johansson KSL, Johnson RK (2013) Factors affecting occurrence and bloom formation of the nuisance flagellate Gonyostomum semen in boreal lakes. harmful. Algae 27:8

Urrutia-Cordero P, Ekvall MK, Ratcovich J, Soares M, Wilken S, Zhang H, Hansson LA (2017) Phytoplankton diversity loss along a gradient of future warming and brownification in freshwater mesocosms. Freshw Biol 62: 1869-1878

Submitted: May 8, 2018; Accepted: October 22, 2018

Proofs received from author(s): December 17, 2018 